\title{
Social Determinants, Working Status, Knowledge and Attitude Regarding Hospital Waste Management Practices in Hospitals of Bengkulu Province
}

\author{
Afriyanto $^{1}$, Somsak Pitaksanurat ${ }^{2}$, Rittirong Junggoth ${ }^{3}$ \\ ${ }^{1}$ Doctoral Student Faculty of Public Health Khon Kaen University, Thailand, ${ }^{2}$ Assistant Professor Faculty of \\ Public Health Khon Kaen University, Thailand, ${ }^{3}$ Faculty of Public Health Khon Kaen University, Thailand
}

\begin{abstract}
Introduction: Healthcare waste are considered infectious and hazardous. It requires specific handling prior to its disposal and poses a stern dangers to ecological, occupational and public health if not managed with caution. Hazardous waste management is a concern for every health care organization and for every healthcare professional.
\end{abstract}

Objective: The objective of the study was to know association demographic social determinants, working status, knowledge and attitude with practice of disposal infectious waste among health personal in hospital Province of Bengkulu

Methodology: A quantitative descriptive cross-sectional Study design was used. The research was carried for the period of five months from February 2019 to August 2019 and the sample size is estimate base on the multiple logistic regressions.

Result: In this study, most of the respondents (42.06\%) not good practice of disposal infectious waste. The multivariate analysis reported age (Adjusted OR: 1.44, 95\% CI: 1.04 to 2.01) with p-value: $<0.030$, education (Adjusted OR: 1.40, 95\% CI: 1.04 to 1.90 ) with p-value: $<0.028$, management system (Adjusted OR: 5.24, 95\% CI: 3.04 to 9.03) with p-value: $<0.001$, knowledge (Adjusted OR: 1.85, 95\% CI: 1.30 to 2.63 with p-value: $<0.001$, attitude (Adjusted OR: $5.21,95 \%$ CI: 3.06 to 8.86 ) with p-value: $<0.001$.

Conclusion: Almost half of hospital health personal had poor practice of disposal handling infectious waste in Bengkulu Province, Indonesia. Infectious waste management system was strongly influence on practice disposal waste.

Keywords: Infectious Waste, Social Determinants, Working Status, Knowledge, Attitude, Hospital Bengkulu.

\section{Introduction}

The hospital is not only a place of patient care but also can be a place of disease spread. Hospital waste may be dangerous to risk to patients but also to other

\section{Corresponding Author:}

Mr. Afriyanto

Doctoral Student Faculty of Public Health Khon Kaen University, Thailand e-mail: afriyanto_nias@kkumail.com Mobile No.: +6281368412361 health workers. Medical waste is very dangerous and then they need special care and management before the final disposal. Every countries have regulatory systems on medical waste depending on their own country's finances, regulations and political capacity as well. Generally, Indonesia have universal waste transfers and transport vehicles that it used to transfer health waste from the point of activities to the care and disposal facilities. Indonesia is the country with the most results from health-care waste across the country. $[1,2,3]$

A research in 2004 indicated that around half of the hospitals surveyed carried out waste separation. 
However, most of Health-Centers activities used to mix their waste at landfills along with domestic waste or burned them in their backyard. Generally overcoming hospital waste has been using incinerators as the most common medical waste handling technology. However, the specifications of their standard operating tools and procedures have not been good yet. The level of knowledge about hospital waste hazards is also very low at all levels of health facility personnel. $\left.{ }^{4,5}\right]$

The absolute number of clinical waste made in Indonesia is around 225 tons every day and the normal/ quiet/bed/day of creation squander - $0.68 \mathrm{~kg} / \mathrm{bed} /$ day.[ $\left.{ }^{6}\right]$

The Management of emergency clinics must oblige data about the threats of irresistible waste and report pretty much the entirety of the means, not simply the isolation cycle. $\left[{ }^{7}\right]$

The population of Bengkulu province in 2015 is $1,874,944$ million people, consists of 10 residences have 22 hospitals that do not perform hospital standard medical waste management. Thus, about health care waste information in Bengkulu province still lack off details information. This study will focus on quantity of infectious waste in hospital, the implementation to integrate it according to regulation and the knowledge and attitude of hospital workers about health care waste at public and private hospitals in Bengkulu Province. $\left[{ }^{8}\right]$

The wrong actions and less of knowledge on the management of handling waste infection will be result to happen of nosocomial infection. Furthermore, several studies have concluded that the advent of pathogenic bacteria in various types of general waste, clinically sharp waste and another waste. The results of research show that clinical solid waste contains various types of nosocomial and practical bacterial pathogens like Staphylococcus aureus and Pseudomonas aeruginosa. $\left[{ }^{9}\right]$

Clinical waste ought to be taken care of appropriately, including irresistible, obsessive, sharps, drug, genotoxic, synthetic squanders, hardcore hefty squanders pressurized compartments and radioactive waste. Good system of waste management can reduce incidence of healthcare workers. The system can reduce the incidence of injection of syringes and nosocomial infections also. It is crucial to create a condition of safe working good atmosphere for health workers. $\left[{ }^{10}\right]$

This paper is an attempt to provide with a review of hospital waste management practices of among workers, who are considered as the integral part of health care and are the focal members of health care team dealing with health care waste.

\section{Methodology}

This studied design with cross sectional study, collect general data for descriptive and after that researcher will conduct with quantitative method and calculated, to know about Practice Infectious Waste Management System (segregation to transportation process) of Socio Demographic factors (age and education attainment), Working Status (occupation, position, work experience, working day/week, working hour/day, average personal income), Management system infectious waste, Knowledge of disposal infectious waste and Attitude infectious waste of health personal at small hospital of Bengkulu Province, Indonesia. The method included questionnaire adopted by government policy in Indonesia.

The sample in this study was taken as many as 825 respondents from 7 hospitals (type B and C) hospitals province of Bengkulu. The research sample consisted of 590 nurses, 129 midwives, 16 sanitation workers and 20 doctors.

The type of dependent variable is a dichotomous outcome and the statistics that use to answer the research question is multiple logistic regressions and the sample size is estimate base on the multiple logistic regressions formula (Hsieh, Bloch, \& Larsen, 1998) and is calculate by software STATA version 14 .

Ethical Consideration: Written Consent from participants was taken before including them in study. The data collected from the correspondents has been kept purely confidential and only used for statistical analysis about study.

\section{Results and Discussion}

The finding of a $40 \%$ not good practice of disposal waste, therefore the future studies might with largest of hospitals. The socio economic characteristics of respondents were showed mean age was $35.79 \pm 6.48$ SD years old consist of male $(26.42 \%)$ and female (73.58\%). They were married (79.03\%) and (20.97\%) single. Almost all of the respondents were Diploma degree $(51.03 \%)$ followed by bachelor degree $(43.88 \%)$, high school (4.48\%) and Master degree (0.61\%). 
The working status characteristics of respondents were showed in table 4 , half of them have working in inpatient unit (64.61\%) have outpatient unit (19.39) and other (16\%). They occupation have nurse $(71.52 \%)$ have midwife (15.64\%) and other (12.84\%). Type position respondent were permanent staff (61.45\%) and temporary staff $(38.55 \%)$ and almost of the respondent have work experience less than 10 years. Most of respondents working more than 6 days per week $(82.42 \%)$ and working more than 8 hours per days $(62.30 \%)$. Monthly per capita income of respondents ranged from 850.000.to 5.000.000 Indonesia Rupiah with the mean 2.399.000 and SD 893.092.

Table 1. Associated with demographic factors in Bengkulu Sumatra is used simple logistic regression.

\begin{tabular}{|c|c|c|c|c|c|}
\hline Independent Variable & Number & \% Poor Practice & OR & $95 \% \mathrm{CI}$ & $\mathbf{P}$ \\
\hline $\begin{array}{l}\text { Age } \\
\geq 35 \\
<35\end{array}$ & $\begin{array}{c}255 \\
92\end{array}$ & $\begin{array}{l}44.12 \\
37.25\end{array}$ & $\begin{array}{c}1 \\
0.75\end{array}$ & 0.55 to 1.02 & 0.0661 \\
\hline $\begin{array}{l}\text { Education } \\
\geq \text { Bachelor Degree } \\
<\text { Bachelor Degree }\end{array}$ & $\begin{array}{l}138 \\
209\end{array}$ & $\begin{array}{l}37.60 \\
45.63\end{array}$ & $\begin{array}{c}1 \\
1.39\end{array}$ & 1.05 to 1.84 & 0.0200 \\
\hline $\begin{array}{l}\text { Occupation } \\
\text { Midwife \& Other } \\
\text { Nurse }\end{array}$ & $\begin{array}{c}98 \\
249\end{array}$ & $\begin{array}{l}41.70 \\
42.20\end{array}$ & $\begin{array}{c}1 \\
1.02\end{array}$ & 0.75 to 1.39 & 0.8952 \\
\hline $\begin{array}{l}\text { Position } \\
\text { Permanent staff } \\
\text { Temporary staff \& Other }\end{array}$ & $\begin{array}{l}209 \\
138\end{array}$ & $\begin{array}{l}41.22 \\
43.40\end{array}$ & $\begin{array}{c}1 \\
1.09\end{array}$ & 0.82 to 1.45 & 0.5385 \\
\hline $\begin{array}{l}\text { Work Experience (Years) } \\
\geq 10 \text { years } \\
<10 \text { years }\end{array}$ & $\begin{array}{l}228 \\
119\end{array}$ & $\begin{array}{l}39.46 \\
48.18\end{array}$ & $\begin{array}{c}1 \\
1.43\end{array}$ & 1.06 to 1.93 & 0.0203 \\
\hline $\begin{array}{l}\text { Working day/week } \\
6 \\
>6\end{array}$ & $\begin{array}{c}281 \\
66\end{array}$ & $\begin{array}{l}41.32 \\
45.52\end{array}$ & $\begin{array}{c}1 \\
1.19\end{array}$ & 0.83 to 1.70 & 0.3543 \\
\hline $\begin{array}{l}\text { Working hour/day } \\
8 \\
>8\end{array}$ & $\begin{array}{c}89 \\
258\end{array}$ & $\begin{array}{l}33.84 \\
45.91\end{array}$ & $\begin{array}{c}1 \\
1.66 \\
\end{array}$ & 1.22 to 2.25 & 0.0010 \\
\hline $\begin{array}{l}\text { Income } \\
\geq 2,000,000 \text { rupiah } \\
<2,000,000 \text { rupiah }\end{array}$ & $\begin{array}{l}238 \\
109\end{array}$ & $\begin{array}{l}41.83 \\
42.58\end{array}$ & $\begin{array}{c}1 \\
1.03\end{array}$ & 0.77 to 1.39 & 0.8400 \\
\hline $\begin{array}{l}\text { Management system } \\
\text { Good ( } \geq 16 \text { scores }) \\
\text { Poor (<16 scores })\end{array}$ & $\begin{array}{l}216 \\
131\end{array}$ & $\begin{array}{l}34.73 \\
64.53\end{array}$ & $\begin{array}{c}1 \\
3.42\end{array}$ & 2.45 to 4.76 & 0.0001 \\
\hline $\begin{array}{l}\text { Knowledge } \\
\text { High (12 - } 20 \text { scores }) \\
\text { Low (0 - } 11 \text { scores })\end{array}$ & $\begin{array}{c}71 \\
276\end{array}$ & $\begin{array}{l}31.98 \\
45.77\end{array}$ & $\begin{array}{c}1 \\
1.80\end{array}$ & 1.30 to 2.48 & 0.0003 \\
\hline $\begin{array}{l}\text { Attitude } \\
\text { Positive ( } \geq 72 \text { scores }) \\
\text { Negative (<72 scores) }\end{array}$ & $\begin{array}{c}283 \\
64\end{array}$ & $\begin{array}{l}38.24 \\
75.29\end{array}$ & $\begin{array}{c}1 \\
4.92\end{array}$ & 2.94 to 8.23 & 0.0001 \\
\hline
\end{tabular}

The results showed that nurses who had low knowledge about treatment process $41.02 \%$ of the total nurses were 686 respondents, midwife had low knowledge about treatment of $37.98 \%$ of the total midwife of 135 respondent, sanitarian officer had low knowledge about treatment and transportation $50 \%$ of the total sanitarian account of 23 respondent and doctors had low knowledge of transportation $30 \%$ of the total doctors of 15 respondent. 
Multiple logistic regression was performed for multivariate analysis which including variable that reported statistical effect on practice in bivariate analysis. The multivariate analysis reported age (Adjusted OR: 1.44, 95\% CI: 1.04 to 2.01$)$ with p-value: $<0.030$, education (Adjusted OR: 1.40, 95\% CI: 1.04 to 1.90 ) with p-value: $<0.028$, management system (Adjusted OR: $5.24,95 \%$ CI: 3.04 to 9.03$)$ with p-value: $<0.001$, knowledge (Adjusted OR: 1.85, 95\% CI: 1.30 to 2.63 with p-value: $<0.001$, attitude (Adjusted OR: 5.21, 95\% CI: 3.06 to 8.86 ) with p-value: $<0.001$ and level of finding information literacy (Adjusted OR: 2.31, 95\% CI: 1.48 to 3.59 ) with p-value: $<0.001$.

In this study, most of the respondents (42.06\%) not good practice of disposal infectious waste, it means that personal health have good practice (57.94\%), age $>35$ years old (44.12\%), high school and diploma (45.63\%). Based on the results of research study conducted in the metropolitan city of Pakistan found that out of 275 including doctors, nurses, paramedics and sanitary workers were interviewed that only $28 \%$ had good practice following the proper guidelines and WHO rules, $>35$ years old $36 \%$ and high school and diploma $\left.(51.6 \%){ }^{[11}\right]$. Furthermore, the practice of officers in the management of medical waste carried out in hospital of Kebumen Indonesia, it was find that (22.2\%) had poor practice while respondents who had good practices obtained results $\left.(77.8 \%) \cdot{ }^{12}\right]$

In line with the findings with present study the research by Hence, Sahiledengle, B. $\left[{ }^{13}\right]$ that reported of four hundred and nine healthcare workers cooperated in the study, for a response rate of $97.4 \%$ were factors that associated with self-reported healthcare waste segregation practice. The differences in the results of this study are due to differences in the number of study samples, locations and research questions. This research is an action that is observe is an active process of activities from segregation to infectious waste disposal of infectious waste.

In light of the outcome, got ordinary and powerful preparing of clinical understudies is significant. Regular mindfulness missions and classes ought to improve the information about safe dealing with and removal of biomedical waste among clinical understudies for future pragmatic application. $\left[{ }^{14}\right]$

\section{Conclusion}

Almost half of hospital health personal had poor practice of disposal handling infectious waste in Bengkulu Province, Indonesia. Infectious waste management system was strongly influence on practice disposal waste. Therefore, hospital should be doing promotion about impact of practice infectious waste. The target of promotion should be all of personal health and the promotion could be using mass media and community in hospital.

Management of Hospital should be provided some poster or brochure which explained about danger of infectious waste and how to prevent. Health care professional should improve their knowledge about infectious waste. Besides, they should discover if poor waste management practices have a bearing on the health of hospital staff.

Future study might be conducted with qualitative studies it can be providing better understanding and knowledge in practice disposal infectious waste.

Conflicts of Interest: All authors declare that they have no competing interest

Source Funding: The Faculty of Public Health, Khon Kaen University of Thailand and University Muhammadiyah Bengkulu of Indonesia for technical support and financial support.

Ethical Consideration: This study was approved by the Human Research and Ethics Committee of Khon Kaen University, Thailand (reference number Ref.KKK 0201.2.3/2450)

\section{References}

1. Ananth AP, Prashanthini V, Visvanathan C. Healthcare waste management in Asia. Waste Management. 2010 Jan 1;30(1):154-61.

2. Indonesia Minister of Environment and Forestry Regulation number P.56 year 2015 on Technical Guideline and Requirement of Hazardous Healthcare Waste Management.

3. Indonesia Regulation number 74, 2001, on Management of Hazardous Substances

4. Irianti S, Herat S. Sustainable Health Care Waste Management in Indonesia: Existing Problems and Proposed Solutions. International Conference on Sustainable Environmental Technology and Sanitation for Tropical Region, Surabaya 2008 Nov (Vol. 19).

5. Irianti S, Prasetyoputra P, Herat S. Determinants of 
hospital waste management in indonesia: focusing on the importance of segregation at source and color-coded collection system. Journal of Applied Sciences in Environmental Sanitation. 2013 Jun $1 ; 8(2)$.

6. WHO. Regional Office for South-East Asia. Report on health-care waste management status in countries of the South-East Asia Region 2017. Available from: http://apps.searo.who.int/PDS_ DOCS/B5353.pdf

7. Pitaksanurat S, Junggoth R, Setiyadi NA. Factors Affecting the Infectious Waste Management System on Practice Disposal Waste Among Health Workers in Bengkulu Hospital. In2nd Sriwijaya International Conference of Public Health (SICPH 2019) 2020 Jun 19 (pp. 101-109). Atlantis Press.

8. Ministry of Health Republic of Indonesia. Indonesia health profile 2015. Available : http://www.kemkes. go.id

9. Hossain $\mathrm{MD}$, Rahman $\mathrm{NN}$, Balakrishnan $\mathrm{V}$, Puvanesuaran VR, Sarker M, Islam Z, Kadir MO. Infectious risk assessment of unsafe handling practices and management of clinical solid waste. International journal of environmental research and public health. $2013 \mathrm{Feb}$;10(2):556-67.
10. Zafar A, Habib F, Hadwani R, Ejaz M, Khowaja K, Khowaja R, Irfan S. Impact of infection control activities on the rate of needle stick injuries at a tertiary care hospital of Pakistan over a period of six years: an observational study. BMC infectious diseases. 2009 Dec 1;9(1):78.

11. Kumar R, Samrongthong R, Shaikh BT. Knowledge, attitude and practices of health staff regarding infectious waste handling of tertiary care health facilities at metropolitan city of Pakistan. Journal of Ayub Medical College Abbottabad. 2013 Jun 1;25(1-2):109-12.

12. Wungo MM, Mahawati E, Hartini E. Hubungan antara pengetahuan dan sikap petugas sanitasi dengan praktik pengelolaan sampah medis di RSUD Kabupaten Kebumen tahun 2013.

13. Sahiledengle B. Self-reported healthcare waste segregation practice and its correlate among healthcare workers in hospitals of Southeast Ethiopia. BMC health services research. 2019 Dec 1;19(1):591.

14. Taarika Balaji, Magendran J. (2020). A Cross Sectional Study on the Awareness on the BioMedical Waste Management among Medical Students in a Tertiary Care Hospital Chennai. Medico Legal Update, 20(2), 199-205. 